\title{
Application of FTIR spectroscopy for analysis of the quality of honey
}

\author{
Monika Kędzierska-Matysek ${ }^{1, *}$, Arkadiusz Matwijczuk ${ }^{2, * *}$, Mariusz Florek ${ }^{1}$, Joanna \\ Barłowska $^{1}$, Anna Wolanciuk ${ }^{1}$, Alicja Matwijczuk ${ }^{2}$, Edyta Chruściel $^{2}$, Radosław \\ Walkowiak $^{2}$, Dariusz Karcz ${ }^{3}$, and Bożena Gładyszewska ${ }^{2}$ \\ ${ }^{1}$ University of Life Sciences in Lublin, Department of Commodity Science and Processing of Raw \\ Animal Materials, 20-950 Lublin, ul. Akademicka 13, Poland \\ ${ }^{2}$ University of Life Sciences in Lublin, Department of Physics, 20-950 Lublin, ul. Akademicka 13, \\ Poland \\ ${ }^{3}$ Krakow Technical University, Department of Analytical Chemistry (C1)
}

\begin{abstract}
Every kind of honey is a very precious natural product which is made by Mellifera bees species. The chemical composition of honey depends on its origin or mode of production. Honey consists essentially of different sugars, predominantly fructose and glucose. There are also nonsugar ingredients like proteins and amino acids, as well as some kind of enzymes, such as: invertase, amylase, glucose oxidase, catalase and phosphatase. The fact that honey is one of the oldest medicine known worldwide is remarkable. Scientists all over the world have been trying to improve analytical methods as well as to implement new ones in order to reaffirm the high quality of honey the benefits of which may be distracted or disturbed. There are many methods and popular analytical techniques, including as follows: mass spectroscopy and molecular spectroscopy (especially FTIR spectroscopy). The infrared spectroscopy technique is one of the most common analytical methods which are used to analyse honey nowadays. The main aim of the task was to use ATR-FTIR infrared spectroscopy to compare selected honey samples as well as typical sequences coming out from certain functional groups in the analysed samples.
\end{abstract}

\section{Introduction}

Honey is a natural product produced by bees of Apis mellifera species from nectar or honeydew. It has a distinctive sweet taste due to a high concentration of sugar i.e. glucose and fructose.
During storage in the vast majority of honeys, a spontaneous crystallization process which determines their consistency takes place [1]. On one hand, the solid phase of honey contains glucose, which is less soluble than fructose. Moreover, glucose can crystallize spontaneously at the room temperature and can be in the form of

\footnotetext{
*Corresponding author: monikakedzierskamatysek@poczta.onet.pl

* Corresponding author: arkadiusz.matwijczuk@up.lublin.pl
} 
$\alpha$-D-glucose, monohydrate and $\alpha$-D-glucose and anhydrous $\beta$ [2-3]. On the other hand, the liquid phase makes up other ingredients, and the most important is the aqueous solution of glucose. The crystallization process of honey continues until equilibrium, i.e. when glucose monohydrate crystals stop growing and do not dissolve [4]. It should be noted that many factors affect honey crystallization. The chemical composition of honey, primarily the type and concentration of sugars, and water content play an important role in this process. Honey during crystallization, in which the ratio of glucose to water $(\mathrm{G} / \mathrm{W})$ is less than 1.7, often tends to delaminate. Crystallization of honey accelerates due to the presence of crystallization germs (i.e. air bubbles, dust, pollen or previously crystallized honey) [5]. The optimum temperature for the crystallization process of honey ranges from $10{ }^{\circ} \mathrm{C}$ to $14{ }^{\circ} \mathrm{C}$. Lupano in his works [6] showed that in honeys stored at $20{ }^{\circ} \mathrm{C}$ large crystals were formed with the melting temperature $\left(\mathrm{T}_{\mathrm{m}}\right)$ ranging from 45 to $65{ }^{\circ} \mathrm{C}$, while in honey stored in temp. - $20{ }^{\circ} \mathrm{C}$ small crystals were formed with the $T_{m}$ ranging from 25 to 45 ${ }^{\circ} \mathrm{C}$.

The crystal structure of honey also depends on the nectar origin. Rapeseed honey is characterized by small and irregular crystals. Crystals in buckwheat honey can be of a considerable size and relatively regular shapes [7]. At this point it is worth to emphasise that the crystallization phenomenon does not adversely affect the quality characteristics of honey [8].

An important tool for determining the crystalline structure of natural honey and its purity is ATR-FTIR IR spectroscopy [9]. This spectroscopy can be successfully applied for the classification of the honey type by replacing the long and timeconsuming pollen analysis. Analysis of honey with the infrared spectroscopy can be used to determine the crystalline structure as well as the purity [2]. It also enables quick determination of the quantitative and qualitative components which define the specific quality of natural honey. The spectra allow distinguishing honeydew honey, artificial, or nectar honey, and the use of specialized software gives the ability to detect even the varieties of the nectars' honey.

FTIR spectrums of natural honeys may significantly differ with some wavelength ranges. It also should be emphasised that very often different bands (in samples) overlap and the sample may not be sufficiently characterized, which can be due to the presence of substances like polysaccharides, water and many other pollutants resulting in a wide band in analytically important spectral ranges. The objective of this paper was to specify certain properties of the selected 5 types of honey using the ATR-FTIR analysis.

\section{Materials and Methods}

Honeys were purchased in the retail network of the city of Lublin. Five types were analyzed, including buckwheat, multifloral, sunflower, linden honey and honeydew with honeydew leaf. According to the declaration of the manufacturers on the labels, honeys were harvested both in the European Community (EC) and non-EC countries. Before the analysis, the samples were stored in a dark place at the room temperature. Honeys have been naturally crystallized to form on the surface of a thin liquid layer. Physical and chemical properties of honey were determined in mixed samples and presented in Table 1 . Water and extract content in honeys was determined by measuring the refractive index by Abbe refractometer Carl Zeiss (Jena, Germany) [10].

$\mathrm{PH}$, free acidity and electrical conductivity of honey were determined as described earlier [10] using pIONneer 65 Meter (Radiometer Analytical, Villeurbanne, CEDEX-France) with a combined $\mathrm{pH}$ electrode (E16M340) and a 4-pole conductivity cell (CDC 30T) with a built-in temperature sensor. 


\subsection{FTIR measurements}

The measurements of ATR-FTIR background-corrected spectra were carried out in solvents using a HATR Ge through ( $45^{\circ}$ cut, yielding 10 internal reflections) a crystal plate for liquids and were recorded with 670-IR spectrometer (Varian, USA). Typically, 25 scans were collected, Fouriertransformed, and averaged for each measurement. The IR absorption spectra at the resolution of one data point per $1 \mathrm{~cm}^{-1}$ were obtained in the region between 4000 and $400 \mathrm{~cm}^{-1}$. The instrument was purged with argon for $40 \mathrm{~min}$ before and during the measurements. The Ge crystal was cleaned with ultra-pure organic solvents (SigmaAldrich Co.) All measurements were taken at the room temperature $\left(\mathrm{T}=23{ }^{\circ} \mathrm{C}\right)$. The spectra was measured both in the mixed and non-mixed samples. All experiments were carried at $20{ }^{\circ} \mathrm{C}$.

\section{Results and discussion}

Table 1 presents physicochemical properties of the analysed honeys. All evaluated honeys met the limits required by the national legislation [11] (The Resolution of the Minister of Agriculture and Rural Development of 18 February 2004 amending the regulation on specific requirements for the commercial quality of honey, Journal of Laws of 2004, no. 40, Item 370 ), in terms of water content, acidity and conductivity (no more than 20\%, 50 $\mathrm{mEq} / \mathrm{kg}$ and $\geq 0.8 \mathrm{mS} / \mathrm{cm}$ for honeydew honeys and $\leq 0.8 \mathrm{mS} / \mathrm{cm}$ for all other subjects). All honeys should be considered as acidic, with a $\mathrm{pH}$ ranging from 3.96 (sunflower) to 4.73 (multifloral). In addition, the moisture content in the analysed honeys ranged from 17.2 (honeydew honey) to 19.4 (linden honey). The content of extract (\%) varied from 79.2 , in the case of linden honey to 81.3 for honeydew honey. Free acid values varied from 4.5 (multifloral honey) to 22 (honeydew honey). Electrical conductivity values ranged between 0.361 (sunflower) and $0.991 \mathrm{mS} / \mathrm{cm}$ (honeydew honey).

Table 1. Physicochemical characteristics of analysed honeys.

\begin{tabular}{|c|c|c|c|c|c|}
\hline Honey type & $\begin{array}{c}\text { Moisture } \\
\text { \% }\end{array}$ & $\begin{array}{c}\text { Extract } \\
\mathbf{\%}\end{array}$ & $\mathbf{p H}$ & $\begin{array}{c}\text { Free acid } \\
\mathbf{m E q} / \mathbf{k g}\end{array}$ & $\begin{array}{c}\text { Electrical } \\
\text { conductivity } \\
\mathbf{m S} / \mathbf{c m}\end{array}$ \\
\hline Buckwheat & 18.6 & 79.9 & 4.65 & 16.5 & 0.537 \\
\hline Multifloral & 18.4 & 80.1 & 4.73 & 4.5 & 0.371 \\
\hline Sunflower & 17.6 & 80.9 & 3.96 & 18.5 & 0.361 \\
\hline Linden & 19.4 & 79.2 & 4.13 & 14.5 & 0.579 \\
\hline Honeydew & 17.2 & 81.3 & 4.60 & 22.0 & 0.991 \\
\hline
\end{tabular}

\subsection{FTIR spectroscopic studies}

Only naturally obtained honey has been used to characterize the spectroscopic properties. In order to compare the samples FTIR spectroscopy was used as an efficient method. Typically, the characteristic differences in the FTIR spectral analysis for natural honeys were observed. It was probably related to the content of carboxylic acids in different types of honey resulting from the floral origin, geographic location and possible environmental pollution [2, 12-17]. Similarly as for alcohols, the $\mathrm{O}-\mathrm{H}$ stretching vibration band in carboxylic acids is very broad and occurs in the field of $3300-2500 \mathrm{~cm}^{-1}$ [18-22] with the maximum at $3000 \mathrm{~cm}^{-1}$. This is the same area as the stretching vibration region for carbon and aromatic C-H groups [23]. Therefore, carboxylic acids are 
characterized by an irregular character of absorption in $3300-2500 \mathrm{~cm}^{-1}$ with a wide range of the $\mathrm{O}-\mathrm{H}$ stretching vibration band for $\mathrm{C}-\mathrm{H}$ [12]. Strong hydrogen bonds present in dimeric carboxylic acids are the reason for the significant extension of the band stretching vibration of the $\mathrm{OH}$ group [24].

The stretching vibration band of the $\mathrm{C}=\mathrm{O}$ carboxylic acids group occurs between 1760-1690 $\mathrm{cm}^{-1}[13,25]$. The exact position of the band depends on whether the acid is saturated or unsaturated, dimerized or associated, etc. The $\mathrm{C}-\mathrm{H}$ band can appear in 1320-1210 $\mathrm{cm}^{-1}$, and the deformation band of the $\mathrm{O}-\mathrm{H}$ group approx. in $1440-1395 \mathrm{~cm}^{-1}$ and $950-910 \mathrm{~cm}^{-1}$ [26]. However, the band under $1440-1395 \mathrm{~cm}^{-1}$ cannot be distinguished from $\mathrm{C}-\mathrm{H}$ bending bands, which also occur in the same frequency region. In general: we observe $\mathrm{O}-\mathrm{H}$ stretching in $3300-2500 \mathrm{~cm}^{-1}$ [27]/ $\mathrm{C}=\mathrm{O}$ stretching in $1760-1690 \mathrm{~cm}^{-1}[26] / \mathrm{C}$ $\mathrm{O}$ stretching in $1320-1210 \mathrm{~cm}^{-1}$ [28]/ O-H bending in 1440-1395 and 950-910 $\mathrm{cm}^{-1}$ [29-30]. To facilitate the characterization of bands and comparison of honeys selected for testing Figure 1 shows an ATR-FTIR spectrum of the tested honeys with major high bands. Table 2 shows the exact position of the bands together with the assignment of relevant vibration to specific functional groups. Table 3 presents a comparative position of the maximum vibration of multifloral and linden honey made from mixing and after thorough mixing of the selected samples for testing.

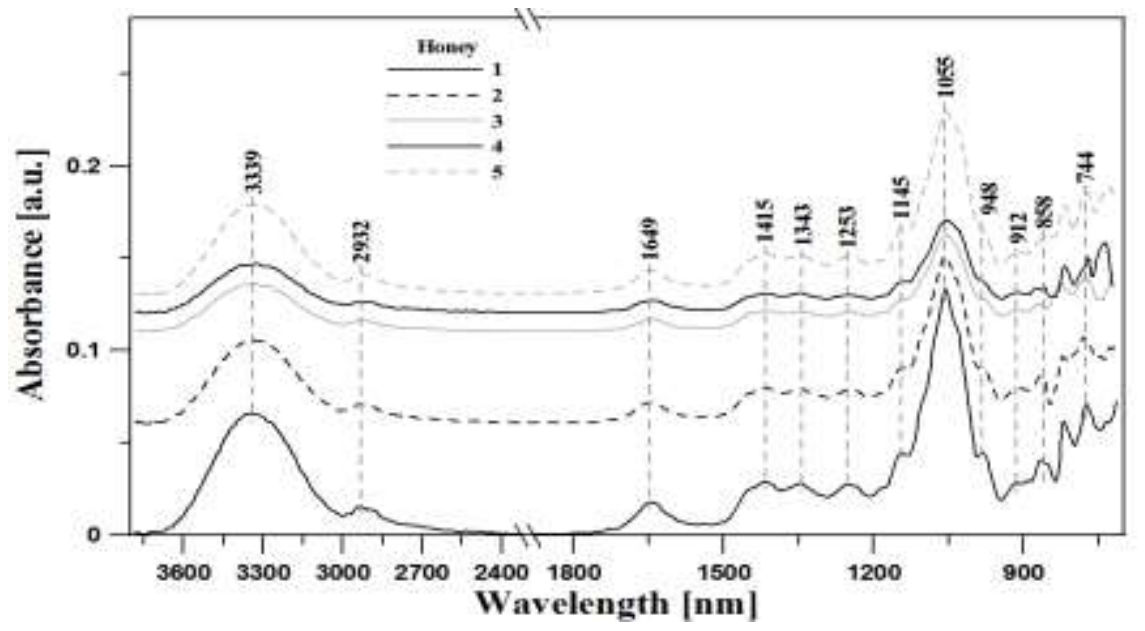

Fig. 1. ATR-FTIR absorption spectra obtained for honeys: 1 - buckwheat honey, 2 - multifloral, 3 sunflower, 4 - linden and 5 - honeydew honey. Detailed data on the locations of specific bands are shown in Table 1.

ATR-FTIR spectra of 5 samples of pure quality honey were obtained in the same conditions, as was described in the materials and methods section. The spectra of the selected honeys observed between 3800 and $700 \mathrm{~cm}^{-1}$ shows four typical absorption zones dominated by two water bands at $3339 \mathrm{~cm}^{-1}\left(v(\mathrm{O}-\mathrm{H})\right.$ and $1649 \mathrm{~cm}^{-1}$ (OH deformation). In the same figure (Fig. 2, Table 2 and Table 3) a band at $2932 \mathrm{~cm}^{-1}$ was observed, which according to Anios et. al. (2015) also corresponds to $\mathrm{C}-\mathrm{H}$ stretching of carboxylic acids and $\mathrm{NH}_{3}$ stretching band of free amino acids. The band from approximately $1500-750 \mathrm{~cm}^{-1}$ corresponds to the most sensitive absorption region of the major components of honey, particularly the most suitable region to quantify honey sugar (about 60$75 \%$ ) and organic acids. The contribution of sucrose, glucose, fructose, show characteristic bands in the region between 
1500 and $900 \mathrm{~cm}^{-1}$. Another important spectral region located at $900-750 \mathrm{~cm}^{-1}$ is characteristic for the saccharide configuration. Authors in many publications define the following spectral peaks as important to sugar characterization.

The vibrations with the maximum bandwidth of about $1450 \mathrm{~cm}^{-1}, \mathrm{~cm}^{-1} 1418$ and $1347 \mathrm{~cm}^{-1}$ are characteristic for bending vibration of $\mathrm{O}-\mathrm{CH}$ and $\mathrm{C}-\mathrm{C}-\mathrm{H}$ in the carbohydrate structure or bending vibration coming from $\mathrm{OH}$ in the $\mathrm{C}-\mathrm{OH}$ grouping. The band range from 1250 to $1140 \mathrm{~cm}^{-1}$ is, in turn, a vibration characteristic for the stretching vibration of the $\mathrm{C}-\mathrm{H}$ in carbohydrates or stretching vibration of $\mathrm{C}$ $\mathrm{O}$ in carbohydrates. The vibrations with the maximum at approximately 1100 and 1080 $\mathrm{cm}^{-1}$ constitute a band that can originate in the vibration of $\mathrm{C}-\mathrm{O}$ in the $\mathrm{C}-\mathrm{O}-\mathrm{C}$ group. Then the area of the bands extending from 1050 to $970 \mathrm{~cm}^{-1}$ of the $\mathrm{C}-\mathrm{O}$ stretching vibrations can be assigned to the $\mathrm{C}-\mathrm{OH}$ group or to the stretching in the carbohydrate structure of C-C. Band with the maximum at approximately $920 \mathrm{~cm}^{-1}$ are bending vibrations bands of the $\mathrm{C}-\mathrm{H}$ group. The last region which is very distinctive in the evaluation and description of honey is the band from 890 to $810 \mathrm{~cm}^{-1}$ characteristic for the vibration anomeric region of carbohydrates or $\mathrm{C}-\mathrm{H}$ deformation.

To sum up the above considerations, distinct differences in the intensity of the bands which are first of all characteristic for vibration of the $\mathrm{OH}$ groups should be also emphasised. These changes inform clearly about varied water content in honey samples selected for testing. The greatest intensity of these bands with the maximum at $3340 \mathrm{~cm}^{-1}$ was in case of buckwheat honey, while the lowest for linden honey and sunflower honeys. The area of bands with the intense maximum at approximately $1055 \mathrm{~cm}^{-1}$ coming from stretching vibrations of both $\mathrm{C}-\mathrm{O}$ in $\mathrm{C}-\mathrm{OH}$ and $\mathrm{C}-\mathrm{C}$ group in the carbohydrate structure also seems to be very interesting. It clearly indicates varied sugar composition of tested samples.

Fructose is the essential sugar in honey with the average value of $36 \%$ ranging from $30 \%$ to $50 \%$ in typical samples. Glucose is the second most representative monosaccharide in honey and varies from $16 \%$ to $34 \%$ with the mean value of $25 \%$. Very significant changes were found also within the area of $900-750 \mathrm{~cm}^{-1}$ which confirms the variable saccharide configuration.

In addition, it is noteworthy to present the differences in the band with the maximum at approximately 1440, 2880, 1410 and 1250 and $1190 \mathrm{~cm}^{-1}$. The above mentioned bands vary with regard to location and this greatly changes the crystals, which have been made in the test samples of honey. These effects will be considered in the subsequent preparation of the topic presented in this article using methods of both spectroscopic and thermographic measurement with the use of differential scanning calorimetry (DSC) and measurements of Raman spectra.

Table 2. Location of maxima of absorption bands FTIR [12-13, 29, 31-34], together with the assignment of appropriate vibration for selected honeys: buckwheat, multifloral, sunflower, linden, and honeydew honey made in terms of spectral $3700-900 \mathrm{~cm}^{-1}$.

\begin{tabular}{|c|c|c|c|c|c|}
\hline \multicolumn{5}{|c|}{ FTIR } & \multirow{3}{*}{$\begin{array}{c}\text { Type and origin } \\
\text { of vibrations }\end{array}$} \\
\hline \multicolumn{5}{|c|}{ Position of bands $\left[\mathrm{cm}^{-1}\right]$} & \\
\hline Buckwheat & Multifloral & Sunflower & Linden & Honeydew & \\
\hline 3340 & 3327 & 3335 & 3325 & 3343 & $v(\mathrm{O}-\mathrm{H})$ in $\mathrm{H}_{2} \mathrm{O}$ \\
\hline 2937 & 2941 & 2932 & 2921 & 2931 & \multirow{2}{*}{$\begin{array}{c}v(\mathrm{C}-\mathrm{H}) \text { or/and } v \\
\left(\mathrm{NH}_{3}\right) \text { of free } \\
\text { amino acids }\end{array}$} \\
\hline 2888 & 2879 & 2875 & 2882 & 2887 & \\
\hline
\end{tabular}




\begin{tabular}{|c|c|c|c|c|c|}
\hline 1646 & 1643 & 1640 & 1644 & 1646 & $\begin{array}{c}\delta(\mathrm{O}-\mathrm{H}) \text { from } \\
\mathrm{H}_{2} \mathrm{O}\end{array}$ \\
\hline 1455 & 1456 & 1451 & 1453 & 1454 & $\begin{array}{c}\delta(\mathrm{O}-\mathrm{CH}) \text { and } \delta \\
(\mathrm{C}-\mathrm{C}-\mathrm{H})\end{array}$ \\
\hline 1415 & 1420 & 1408 & 1418 & 1417 & $\begin{array}{c}\delta(\mathrm{O}-\mathrm{H}) \text { in } \mathrm{C}-\mathrm{OH} \\
\text { group }+\delta(\mathrm{C}-\mathrm{H}) \\
\text { in the alkenes }\end{array}$ \\
\hline 1347 & 1345 & 1344 & 1347 & 1342 & $\begin{array}{l}\delta(-\mathrm{OH}) \text { in } \mathrm{C}-\mathrm{OH} \\
\text { group }\end{array}$ \\
\hline 1249 & 1256 & 1253 & 1253 & 1259 & \multirow{2}{*}{$\begin{array}{c}v(\mathrm{C}-\mathrm{H}) \text { in } \\
\text { carbohydrates } \\
\text { or/and } v(\mathrm{C}-\mathrm{O}) \text { in } \\
\text { carbohydrates }\end{array}$} \\
\hline 1189 & 1186 & 1193 & 1189 & 1189 & \\
\hline 1143 & 1145 & 1145 & 1153 & 1148 & $\begin{array}{c}v(\mathrm{C}-\mathrm{H}) \text { in } \\
\text { carbohydrates } \\
\text { or/and } v(\mathrm{C}-\mathrm{O}) \text { in } \\
\text { carbohydrates }\end{array}$ \\
\hline 1101 & 1101 & 1102 & 1103 & 1105 & \multirow{2}{*}{$\begin{array}{l}v(\mathrm{C}-\mathrm{O}) \text { in } \mathrm{C}-\mathrm{O}-\mathrm{C} \\
\text { group }\end{array}$} \\
\hline 1078 & 1080 & 1076 & 1080 & 1079 & \\
\hline 1055 & 1056 & 1056 & 1056 & 1055 & \multirow{5}{*}{$\begin{array}{l}v(\mathrm{C}-\mathrm{O}) \text { in } \mathrm{C}-\mathrm{OH} \\
\text { group or } v(\mathrm{C}-\mathrm{C}) \\
\text { in the } \\
\text { carbohydrate } \\
\text { structure }\end{array}$} \\
\hline 1033 & 1032 & 1032 & 1033 & 1033 & \\
\hline 1014 & 1011 & 1012 & 1017 & 1014 & \\
\hline 981 & 981 & 978 & 985 & 982 & \\
\hline 966 & 966 & 964 & 976 & 964 & \\
\hline 917 & 917 & 923 & 933 & 920 & $\delta(\mathrm{C}-\mathrm{H})$ \\
\hline 895 & 897 & 894 & 897 & 892 & \multirow{4}{*}{$\begin{array}{l}\text { anomeric region } \\
\text { of carbohydrates } \\
\quad \text { or } \delta(\mathrm{C}-\mathrm{H})\end{array}$} \\
\hline 866 & 866 & 866 & 868 & 861 & \\
\hline 844 & 830 & 839 & 846 & 839 & \\
\hline 819 & 815 & 814 & 816 & 820 & \\
\hline
\end{tabular}

$v-$ stretching vibrations, $\delta$ - deformation vibrations, $\mathrm{s}-$ symmetric, as - asymmetric, st - strong, denotes frequencies that may originate from the solvent used

Table 3. Location of maxima of FTIR absorption bands with arrangement of appropriate vibration for selected honeys: multifloral, linden (mixed and non-mixed) in terms of spectral $3700-900 \mathrm{~cm}^{-1}$.

\begin{tabular}{|c|c|c|c|c|}
\hline \multicolumn{4}{|c|}{ FTIR } & \multirow{4}{*}{$\frac{\text { Type and origin of }}{\underline{\text { vibrations }}}$} \\
\hline \multicolumn{4}{|c|}{ Position of bands $\left[\mathrm{cm}^{-1}\right]$} & \\
\hline \multicolumn{2}{|c|}{ Multifloral } & \multicolumn{2}{|c|}{ Linden } & \\
\hline mixed & non-mixed & mixed & non-mixed & \\
\hline 3337 & 3327 & 3333 & 3325 & $v(\mathrm{O}-\mathrm{H})$ in $\mathrm{H}_{2} \mathrm{O}$ \\
\hline 2934 & 2941 & 2929 & 2921 & \multirow{2}{*}{$\begin{array}{c}v(\mathrm{C}-\mathrm{H}) \text { or/and } v \\
\left(\mathrm{NH}_{3}\right) \text { of free amino } \\
\text { acids }\end{array}$} \\
\hline 2888 & 2879 & 2888 & 2882 & \\
\hline 1644 & 1643 & 1647 & 1644 & $\delta(\mathrm{O}-\mathrm{H})$ from $\mathrm{H}_{2} \mathrm{O}$ \\
\hline 1446 & 1456 & 1453 & 1453 & $\begin{array}{c}\delta(\mathrm{O}-\mathrm{CH}) \text { and } \delta(\mathrm{C}- \\
\mathrm{C}-\mathrm{H})\end{array}$ \\
\hline 1412 & 1420 & 1417 & 1418 & $\delta(\mathrm{O}-\mathrm{H})$ in $\mathrm{C}-\mathrm{OH}$ \\
\hline
\end{tabular}




\begin{tabular}{|c|c|c|c|c|}
\hline & & & & $\begin{array}{l}\text { group }+\delta(\mathrm{C}-\mathrm{H}) \text { in } \\
\text { the alkenes }\end{array}$ \\
\hline 1346 & 1345 & 1348 & 1347 & $\begin{array}{c}\delta(-\mathrm{OH}) \text { in } \mathrm{C}-\mathrm{OH} \\
\text { group }\end{array}$ \\
\hline 1253 & 1256 & 1247 & 1253 & \multirow{2}{*}{$\begin{array}{c}v(\mathrm{C}-\mathrm{H}) \text { in } \\
\text { carbohydrates or/and } \\
v(\mathrm{C}-\mathrm{O}) \text { in } \\
\text { carbohydrates }\end{array}$} \\
\hline 1189 & 1186 & 1182 & 1189 & \\
\hline 1147 & 1145 & 1149 & 1153 & $\begin{array}{c}v(\mathrm{C}-\mathrm{H}) \text { in } \\
\text { carbohydrates or/and } \\
v(\mathrm{C}-\mathrm{O}) \text { in } \\
\text { carbohydrates }\end{array}$ \\
\hline 1100 & 1101 & 1103 & 1103 & \multirow{2}{*}{$\begin{array}{l}v(\mathrm{C}-\mathrm{O}) \text { in } \mathrm{C}-\mathrm{O}-\mathrm{C} \\
\text { group }\end{array}$} \\
\hline 1081 & 1080 & 1080 & 1080 & \\
\hline 1056 & 1056 & 1055 & 1056 & \multirow{5}{*}{$\begin{array}{l}v(\mathrm{C}-\mathrm{O}) \text { in } \mathrm{C}-\mathrm{OH} \\
\text { group or } v(\mathrm{C}-\mathrm{C}) \text { in } \\
\text { the carbohydrate } \\
\text { structure }\end{array}$} \\
\hline 1031 & 1032 & 1038 & 1033 & \\
\hline 1014 & 1011 & 1012 & 1017 & \\
\hline 981 & 981 & 981 & 985 & \\
\hline 965 & 966 & 966 & 976 & \\
\hline 918 & 917 & 923 & 933 & $\delta(\mathrm{C}-\mathrm{H})$ \\
\hline 896 & 897 & 893 & 897 & \multirow{4}{*}{$\begin{array}{l}\text { anomeric region of } \\
\text { carbohydrates or } \delta \\
(\mathrm{C}-\mathrm{H})\end{array}$} \\
\hline 867 & 866 & 862 & 868 & \\
\hline 835 & 830 & 844 & 846 & \\
\hline 815 & 815 & 817 & 816 & \\
\hline
\end{tabular}

$v$ - stretching vibrations, $\delta$ - deformation vibrations, $\mathrm{s}-$ symmetric, as - asymmetric, st - strong, * denotes frequencies that may originate from the solvent used

\section{Conclusions}

In conclusion this paper referred to some physicochemical properties of the selected types of honey. Evaluated honeys met the limits required by the national legislation in terms of water content, free acid and electrical conductivity. The moisture content in all samples differed significantly as shown by both the physicochemical and spectroscopic measurement. Application of analysis of ATR-FTIR indicated key areas that serve both determination of the composition of the honey samples selected for testing and may also be used to determine the region of origin of these samples. The infrared spectroscopy analysis results confirm significant variation of the water content in the samples as well as the variable composition of the sugar in the selected samples.
The samples that before the measurements of the spectrum have not been mixed were also the location of the maximum bands assigned to the structures that we associate with the process of crystallization in honeys. FTIR-ATR showed to be a reliable method to quantify the majority of the sugar content in honey and is easily adapted to routine analysis of this product.

\section{References}

1. A. Oryan, E. Alemzadeh, A. Moshiri J Tissue Viability. 25, 98-118 (2016)

2. I. Martos, F. Ferreres, F.A. TomásBarberán J Agric Food Chem. 48, 1498-1502 (2000)

3. F. E. Young J. Phys. Chem. 61, 616619 (1957)

4. S. Bakier Pszczelarstwo 4, 2-4 (2007) 
5. Y.W.Chen C.H. Lin, F.Y. Wu, H.H. Chen J Food Process Eng 32, 512-527 (2009)

6. C.E. Lupano Food Res Int 30, 683-688 (1997)

7. S. Bakier Postępy Techniki Przetwórstwa Spożywczego 16, 30-34 (2006)

8. R. Subramanian, H. Umesh Hebbar, N. Rastogi Int J Food Prop 10, 127143 (2007)

9. S.Sivakesava, J. Irudayaraj J. Sci. Food Agric 81, 683-690 (2001)

10. Bogdanov, S. The honey book (2009)

11. J.S. Zegar $Z$ badań nad rolnictwem społecznie zrównoważonym (10). Raport końcowy, synteza i rekomendacje, Instytut Ekonomiki Rolnictwa i Gospodarki Żywnościowej-Państwowy Instytut Badawczy, 2009.

12. S. Gok, M. Severcan, E. Goormaghtigh, I. Kandemir, F. Severcan Food Chem. 170, 234-240 (2015)

13. O. Anjos, M.G. Campos, P.C. Ruiz, P. Antunes Food Chem. 169, 218-223 (2015)

14. B. Özbalci, İ.H. Boyaci, A. Topcu, C. Kadilar, U. Tamer Food Chem. 136, 1444-1452 (2013)

15. L. Lenhardt, R., Bro, I. Zeković, T. Dramićanin, M.D. Dramićanin Food Chem. 175, 284-291 (2015)

16. X. Yang, Y. Zhuo, S. Zhu, Y. Luo, Y., Feng, Y., Dou Biosens. Bioelectron. 60, 292-298 (2014)

17. H. Madupalli, B. Pavan, M.M. Tecklenburg J. Solid State Chem. 255, 27-35 (2017)

18. Z. Gan, Y., Yang, J. Li, X. Wen, M. Zhu, Y. Jiang, Y. Ni J Food Eng 178, 151-158 (2016)

19. U. Turaga, V. Singh, A. Gibson, S. Maharubin, C. Korzeniewski, S. Presley, E. Smith, R.J. Kendall, S. Ramkumar AATCC Rev 3, 25-31 (2016)

20. E.M. Nickless, S.E. Holroyd, G. Hamilton, K.C. Gordon, J.J. Wargent
Vibrational Spectroscopy 84, 38-43 (2016)

21. N.I. Zakaria, A.R. Yacob eProceedings Chemistry 2, (2017)

22. E. Mellado-Mojica, N.P. Seeram, M.G. López J. Food Comp. Anal. 52, 1-8 (2016)

23. L. Svečnjak, S. Prđun, J. Rogina, D. Bubalo, I. Jerković Food Chem. 232, 286-294 (2017)

24. H.E. Tahir, Z. Xiaobo, L. Zhihua, S. Jiyong, X. Zhai, S. Wang, A.A. Mariod Food Chem. 226, 202-211 (2017)

25. I. Kasprzyk, J. Depciuch, D. GrabekLejko, M. Parlinska-Wojtan Food Control (2017)

26. S. Li, X. Zhang, Y. Shan, D. Su, Q. Ma, R. Wen, J. Li Food Chem. 218, 231-236 (2017)

27. N. Cebi, M.Z. Durak, O.S. Toker, O. Sagdic, Arici, M. Food Chem. 190, 1109-1115 (2016)

28. G. Bázár, R. Romvári, A. Szabó, T. Somogyi, V. Éles, R. Tsenkova Food Chem. 194, 873-880 (2016)

29. K. Ruoff, W. Luginbühl, R. Künzli, M.T. Iglesias, S. Bogdanov, J.O. Bosset, K. von der Ohe, W. von der Ohe, R. Amadò J Agric Food Chem. 54, 6873-6880 (2006)

30. F. Anguebes, L. Pat, B. Ali, A. Guerrero, A.V. Córdova, M. Abatal, J.P. Garduza J Anal Methods Chem 2016, 1-14 (2016)

31. N.F.M. Sabri, H.H. See, H. H. eProceedings Chemistry 1, 22-26 (2016)

32. P. Mühlschlegel, A. Hauk, U. Walter, R. Sieber Food Addit Contam 1-8 (2017)

33. H. Dong, D. Luo, Y. Xian, H. Luo, X. Guo, C. Li, M. Zhao J. Agric. Food Chem 64, 3258-3265 (2016)

34. C. Das, S. Chakraborty, K. Acharya, N.K., Bera, D. Chattopadhyay, A. Karmakar, S. Chattopadhyay Talanta 171, 327-334 (2017) 